\title{
7. \\ The echoes of diplomatic disputes. The Macedonian Question in the work of Serbian and Yugoslav music scholars
}

\author{
Ivana Vesić
}

As the Great Eastern Crisis was approaching in the mid-1870s, the conflicting political interests of neighboring Balkan peoples started to manifest. ${ }^{1}$ Claiming primacy over the same territory of the Ottoman Empire and its inhabitants in their mutually excluding national projects, political elites of the Balkans initiated longstanding political and diplomatic struggles that did not lose intensity over the course of time. The so-called Macedonian Question became one of the most important points of dispute between the countries of this part of Europe at the time, imposing itself as an almost insurmountable obstacle in the relations between Serbian and Bulgarian elites since the second half of the $19^{\text {th }}$ century. The end of the Second Balkan War (1913), and even more so the Great War with the Treaty of Neuilly between the Kingdom of Serbs, Croats and Slovenes (SCS) and the Kingdom of Bulgaria (1920) did not bring a stabilization of the political situation in the region. On the contrary, the fact that the territory of Vardar Macedonia was recognized as part of the newly founded Yugoslav Kingdom fueled fierce reactions of the Bulgarian side throughout the interwar period. ${ }^{2}$

The Bulgarian-Yugoslav political and diplomatic conflict was reflected in their internal and foreign policies, but also left a deep mark on the academic, cultural and public spheres of the two countries. Various intellectual, artistic

\footnotetext{
1 See Victor Roudometof (Ed.), The Macedonian Question: Culture, Historiography, Politics (East European Monographs, 2000); Victor Roudometof, Collective Memory, National Identity, and Ethnic Conflict: Greece, Bulgaria, and the Macedonian Question (Praeger Publishers, 2002); Vladislav B. Sotirović, "Macedonia between Greek, Bulgarian, Albanian, and Serbian National Aspirations, 1870-1912," Serbian Studies: Journal of the North American Society for Serbian Studies 23/1 (2009): 17-40.

2 See Živko Avramovski (Ed.), Jugoslovensko-bugarski odnosi u XX veku [Yugoslav-Bulgarian Relations in the $20^{\text {th }}$ Century], Vol. 1 (Belgrade: Institut za savremenu istoriju, Narodna knjiga, 1980); Živko Avramovski (Ed.) Jugoslovensko-bugarski odnosi u XX veku, Vol. 2 (Belgrade: Institut za savremenu istoriju, Narodna knjiga, 1982); Dragan Bogetić, Slobodanka, Kovačević, Hronologija jugoslovensko-bugarskih odnosa 1878-2003 [Chronology of Yugoslav-Bulgarian Relations 1878-2003] (Belgrade: Jugoistok XXI, Centar za evro-balkansku saradnju, 2003);
} 
and political circles contributed to the struggle of their authorities against the neighbors by reproducing or elaborating on the official discourse on Macedonia and Macedonians, as well as interpretations of their ethnical and cultural characteristics. ${ }^{3}$ Despite Yugoslavia's formal sovereignty over Vardar Macedonia, the fear of Bulgarian influence on the "fluctuating" and instable Macedonian identity stimulated extensive work on economic, cultural and political emancipation and integration of this region, and on contesting the validity of Bulgarian claims in the domestic and foreign public. ${ }^{4}$ The actions of Yugoslav authorities were followed by numerous initiatives of Belgrade-based women's, patriotic and academic associations and organizations that aimed at bringing Macedonians closer to the Serbian cultural space and at the same time away from Bulgarian bailiwick. ${ }^{5}$ Musicians and music experts, particularly of Serbian origin, also played role in this process.

Cultural integration of Vardar Macedonia into the Kingdom of Yugoslavia was based to a great extent on the experience of prewar cultural work of the Serbian political and intellectual elite. The same actors and methods were employed, as well as the same ideology. This was also typical for the various activities concerning the performing, research and production in music at the time. As we shall discuss in subsequent sections, not only were interwar musicians and music experts and scholars-intentionally or unintentionally-giving their support to the process of making Macedonians Serbs and Yugoslavs, and consequently defending the Yugoslav position against the Bulgarian stance, but they also followed the directions of their predecessors. Moreover, the idea of ethnical and cultural closeness of Serbs and Macedonians was internalized to such a degree that they felt no need whatsoever to explain it. This phenomenon was brought to light particularly in the studies of traditional folk music of Vardar Macedonia created at the time as well as in the rare debates with foreign researchers on that topic.

\footnotetext{
3 See, for instance, Ljubinka Trgovčević, Naučnici Srbije i stvaranje jugoslovenske države 1914-1920 [Serbian scientists and the establishing of a Yugoslav state 1914-1920] (Belgrade: Narodna knjiga, Srpska književna zadruga, 1986); Sofija Božić, "Makedonija kao sporno pitanje između Srpske kraljevske akademije i Bugarske akademije nauka 1913 [Macedonia as an issue between the Serbian Royal Academy and the Bulgarian Academy of Sciences 1913]," in Balkanski ratovi 1912-1913: nova viđenja i tumačenja, edited by Srđan Rudić, Miljan Milkić (Belgrade: Istorijski institut, Institut za strategijska istraživanja, 2013), 381-392.

4 Cf. Vladan Jovanović, "Demografske odlike Vardarske banovine i problemi samoidentifikacije [The demographic characteristics of the Vardar Banovina, and the problems of self-identification]," Etnoantropološki problemi 1 (2012): 563-584.

5 See the discussion in the following sections.
} 


\section{Cultural initiatives of the Serbian and Yugoslav elite regarding Vardar Macedonia (1860s-1930s)}

Interest for initiating cultural actions on the territory of Vardar Macedonia among the Serbian political and intellectual elite appeared as early as the late 1860s, manifested in the foundation of the Committee for Serbian Schools of Old Serbia and Macedonia (1868-1876), ${ }^{6}$ and after the Serbian-Turkish (1876-1878) and Russian-Turkish (1877-1878) wars also in the various projects aiming at strengthening Serbian influence in the domains of education, religious affairs and publishing. ${ }^{7}$ Alongside the official endeavors of the Serbian government regarding the expansion of educational institutions in Old Serbia and Macedonia under their control, Belgrade-based intellectual circles utilized the stronger presence of Serbian Orthodox Church clerics and Serbian diplomats in this part of the Ottoman Empire, as well as the export of school books and literature, to develop diverse forms of cultural work aimed at intensifying cultural and national bonding of Macedonians with the then Kingdom of Serbia and promoting their cultural heritage in the public. Among them a prominent place belonged to the Saint Sava Society, established in 1886, which assisted the schooling of locals from Old Serbia and Macedonia in Belgrade before the outbreak of the Balkan Wars, helped repair church and school buildings, and published books and materials supporting Serbian aspirations toward these regions. ${ }^{8}$ Certain women's societies and associations also contributed to this process, including the prestigious and influential Circle of Serbian Sisters (Kolo srpskih sestara) founded in 1903.

A number of choral societies as well as musicians took part in the making of Macedonian and Old Serbian traditional culture part of the Serbian national culture, presenting and popularizing its artifacts to the Serbian public. Renowned Serbian composers of the time, most of whom were the leading choirmasters of Belgradebased and provincial amateur ensembles, showed great interest in songs and dances from Macedonia and Kosovo and their artistic remodeling as documented in a detailed study by musicologist Srđan Atanasovski. ${ }^{9}$ Josif Marinković (1851-1931),

\footnotetext{
6 See more in Slaviša Nedeljković, "Delovanje Odbora za škole i učitelje u srpskim oblastima u Makedoniji od 1868. do 1876. [The functioning of the Committee for Schools and Teachers in Serbian areas in Macedonia from 1868 to 1876]," Vardarski zbornik 8 (2011): 283-305.

7 See more in Miloš Jagodić, "Planovi o politici Srbije prema Staroj Srbiji i Makedoniji (1878-1885) [Plans on the policies of Serbia toward Old Serbia and Macedonia (1878-1885]," Istorijski časopis LX (2011): 435-460.

8 See Jovan Hadži-Vasiljević, "Prilike pod kojima je postalo Društvo Sv. Save i njegov rad od postanka do sada [The circumstances of the foundation of the St. Sava Society and its work from the beginning until today]," Bratstvo XVIII (1924): 1-14.

9 Srđan Atanasovski, Mapiranje Stare Srbije. Stopama putopisaca, tragom narodne pesme [The Mapping of Old Serbia: In the Footsteps of Travel Writers, Tracing the Folk Song] (Belgrade: Biblioteka XX vek, 2017).
} 
Isidor Bajić (1878-1915), Vladimir Đorđević (1869-1938) and above all Stevan Stojanović Mokranjac (1856-1914) were intrigued by the music material from these regions, which served as a basis for some of their most appreciated works composed in the late $19^{\text {th }}$ and early $20^{\text {th }}$ century. Apart from using traditional music from Macedonia as a creative source, some composers initiated its preservation and exploration. ${ }^{10}$ In both cases, the narratives of the Serbian political and intellectual elite were typically reflected and reproduced. The idea of national and cultural unity of Serbs and Macedonians was deemed undeniable, and along with it the aspirations of the Kingdom of Serbia for territorial expansion and annexation of Old Serbia and Macedonia. Traditional music from this part of the Ottoman Empire was considered one of the numerous indicators of ethnical similarity between these peoples, and consequently contributed to legitimizing the Serbian elite's political program. ${ }^{11}$

Although the end of the Great War brought the realization of long-awaited political goals of the Serbian elite, specifically concerning the territorial incorporation of Vardar Macedonia into the Kingdom of SCS, 12 this fact did not discourage the continuation of the process of cultural integration of Macedonians. On the contrary, it intensified in the interwar period, which was largely the result of the circumstances faced in the field, such as the lack of strong Serbian and Yugoslav national consciousness among Macedonians and their general volatility regarding the issue of national identity. Consequently, many initiatives took place in the 1920s and 1930s whose aim was to foster stronger bonding of Slavs in this region with the Yugoslav state and society, and to stimulate the appropriation of Serbian and Yugoslav national and cultural identity. For this purpose, the Faculty of Philosophy was founded in Skopje in 1920,13 and soon after, as its important parts, the Scientific Society of Skopje, which published a very esteemed journal, Glasnik Skopskog naučnog društva (The Bulletin of the Skopje Scientific Society), since 1925, as well as the Society for Serbian Language and Literature. Although

\footnotetext{
${ }^{10}$ Ibid., 110-191. Actually, only Mokranjac went beyond the borders of the Ottoman Empire for the purpose of collecting folk tunes (1896, Prishtina). Đorđević and Bajić collected music material in the southern parts of the Kingdom of Serbia, closest to the Old Serbia and Macedonia regions. ${ }^{11}$ Ibid., 110-191. Cf. Biljana Milanović, "Stevan Stojanović Mokranjac i aspekti etniciteta i nacionalizma [Stevan Stojanović Mokranjac and the aspects of ethnicity and nationalism]," in Mokranjcu na dar, edited by Ivana Perković Radak, Tijana Popović Mlađenović (Belgrade: Fakultet muzičke umetnosti, 2006), 33-53; Srđan Atanasovski, "Stevan Stojanović Mokranjac and Producing the Image of Serbian Folk-Song: Garlands from 'Old Serbia' as a Form of Musical Travelogue," Muzikološki zbornik 1 (2014): 75-90.

${ }^{12}$ On the coining of the term Vardar Macedonia see Dejan D. Antić, "Političke prilike i srpski narod u Vardarskoj Makedoniji (1903-1912) [Political circumstances and the Serbian people in Vardar Macedonia]," (PhD diss., Faculty of Philosophy of the University of Niš), 19-23.

${ }^{13}$ See "Pitanje o broju fakulteta (memoar komisije) [The issue of the number of faculties (Commission memoir)]," Prosvetni glasnik 2 (1928): 181-210.
} 
its construction started as early as 1915, after numerous changes to the plans and delays, the National Theater of King Alexander I was opened in Skopje in 1927, and the monumental new building, together with the Skopje theater ensemble, was expected to serve the national interests and contribute to the national and cultural emancipation of "our dear South." 14 Various women's, patriotic, sports and humanitarian organizations that were established in the Kingdom of Serbia before the Balkan Wars opened their branches throughout the urban centers of Vardar Macedonia, at the time part of the South Serbia province, ${ }^{15}$ in order to encourage locals to participate in political, educational, sports or artistic activities, but also to support their overall cultural and economic integration. ${ }^{16}$

A contribution in this process was, similarly to the prewar period, made by musicians and music associations, mostly through the domains of music performances and ethnography (see Figure 1). One of the oldest and most prestigious choirs from Belgrade, the Obilić Academic Choral Society (founded in 1884), regularly organized tours in "South Serbia" from 1923 onward, ${ }^{17}$ which beside concert performances included visits to important places from Serbian recent and distant past, and interaction with local associations and authorities. The intertwining of different tasks was well evidenced through a series of reports created during the Obilić tour around the region called South Serbia in 1925 by writer and journalist Gustav Krklec (1899-1977) published in the daily Vreme (Time). ${ }^{18}$

\footnotetext{
${ }^{14}$ See "Danas se svečano otvara nova zgrada Narodnog pozorišta Kralja Aleksandra I [Today is the ceremonial opening of the new building of the National Theater of King Alexander I]," Vreme (October 27, 1927): 4.

${ }^{15}$ On the administrative divisions of the Kingdom of SCS/Yugoslavia and the naming of the territory formerly known as Old Serbia and Macedonia, see Vladan Jovanović, Jugoslovenska država i Južna Srbija 1918-1929. Makedonija, Sandžak i Kosovo i Metohija u Kraljevini SHS [The Yugoslav State and South Serbia 1918-1929. Macedonia, Sanjak, and Kosovo and Metohija in the Kingdom of SCS] (Belgrade: Institut za noviju istoriju Srbije, 2002), 7-10.

16 See, for instance, "Izveštaj o radu Narodnog ženskog saveza Kraljevine SHS u 1924-25 [Report on the work of the National Women's Association of the Kingdom of SCS in 1924-25]," Ženski pokret 8 (1925): 274-285.

17 The Obilić Academic Choir visited Skopje, Kumanovo, Bitola, Ohrid and Prishtina in 1923, and partly repeated the same route in 1925, 1927, 1933 and 1937. See more in Boro Majdanac, Milena Radojčić (Eds.), Akademsko pevačko društvo Obilić 1884-1941: dokumenti, sećanja, komentari [The Obilić Academic Choral Society 1884-1941: Documents, Memories, Comments] (Belgrade: Istorijski arhiv Beograda, 2005).

${ }^{18}$ Krklec wrote five travelogues, each describing the specific phenomena he and his fellow visitors encountered on tour: "U Dušanovoj prestonici na obalama Vardara [In Dušan's capital on the banks of the Vardar River]," Vreme (July 7, 1925): 5; "U Prizrenu - srpskom Carigradu [In Prizren-the Serbian Constantinople]," Vreme (July 12, 1925): 5; "Sjaj i lepota Visokih Dečana [The brilliance and beauty of Visoki Dečani] Vreme (July 17, 1925): 3; "Tragovima Albanske golgote [In the footsteps of the Albanian Golgotha]," Vreme (July 21, 1925): 4; "Srce Metohije. Varošica Peć, sedište stare srpske Patrijaršije i njena okolina [In the heart of Metohija. The town of Peć/Peja, the seat of the old Serbian Patriarchy and its surroundings]," Vreme (July 24, 1925): 6.
} 
Krklec emphasized in his miniatures the commemorative and historical aspects of the tour with references to the Albanian Golgotha of the Serbian army during the WWI, Serbian Emperor Dušan's 14th century capital (Skopje), the greatness of his father's and his endowment Visoki Dečani, and at the same time tried to depict the specific atmosphere of South Serbian urban areas, mostly unknown to his readers. It was through these and similar occasions that Macedonians were given the opportunity to listen to what was considered core Serbian and Yugoslav artistic music, part of which was inspired by their own local traditional music (see Figure 2). Whether the familiarity of the tunes made an impression on the local audience, and whether the contact with the dominant musical culture (Serbian and Yugoslav) had an impact on the understanding of the musical heritage of that region is, unfortunately, hard to conclude from the short and uninformative press reports, which are mostly completely oblivious to the views of the locals.

The idea of indivisibility of Macedonian, Serbian and Yugoslav music that was reflected in the sphere of music performance was even more accentuated in the music ethnography undertakings of the 1920s and 1930s. The great interest in researching the traditional folk music of Vardar Macedonia was primarily expressed by Serbian scholars soon after the Great War. It was brought to light in their correspondence with the Arts Department of the Ministry of Education as well as the writings they published in the daily press, music periodicals and scientific journals. ${ }^{19}$ The fact that this region was generally unexplored and that very few scholars of Serbian origin had the chance to explore its musical heritage in situ since the late $19^{\text {th }}$ century, along with the assumption that traditional folk music was rapidly disappearing owing to the expansion of popular music practices, led them to believe in the necessity of broad and systematically conceived fieldwork on the territory of South Serbia. ${ }^{20}$ Despite the enthusiasm and willingness they displayed for conducting such research, there were many financial and organizational obstacles that stood on their way. In fact, problems regarding the creation of an adequate institutional framework for conducting ambitious research projects propagated by Serbian scholars persisted throughout the interwar period particularly in Belgrade, contributing to a large extent to a reduced number of field studies and frequent changes to research plans.

\footnotetext{
${ }^{19}$ Details will be discussed in the next section.

${ }^{20}$ Cf. Ivana Vesić, Konstruisanje srpske muzičke tradicije u periodu između dva svetska rata [The Constructing of the Serbian Music Tradition in the Period between the Two World Wars] (Belgrade: Muzikološki institut SANU, 2018), 231-235.
} 


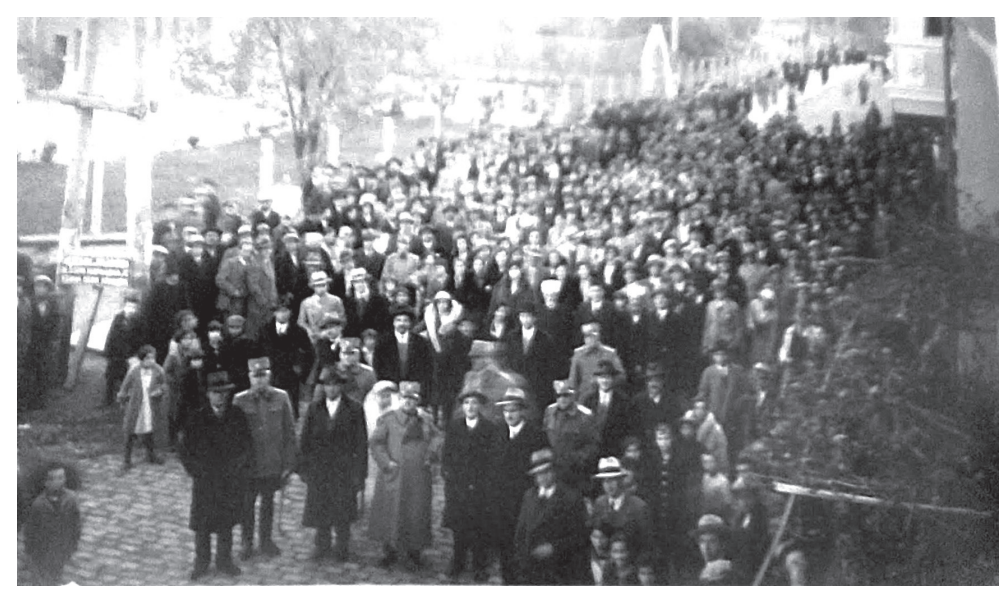

Figure 1. A tour of Music Society of Novi Sad around Serbia and South Serbia (1932), a scene from Bitola. Institute of Musicology SASA,

Legacy of Svetolik Pašćan Kojanov, unsigned.

Th IOI TOKPOBHT $\mathrm{KPABA}$ JУ AЛЕКСAH A ЈУЖНОС CABE3HO M HOBOM CAДY

TУРНG КРОЗ СРБИЈУ И ЈУЖКНУ СРБИЛУ

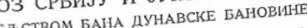
ПОЛ ПОКРОВИТЕЛСТВОМ БАНА ДУНАВСКЕ БАНО НИ ГOCIOДИНA MUЛАНA HИKOЛИTA

\section{Iротрам коншерта} јутословенске хорске музике KРУUЕВАШ НИШ ЛЕСКОВАI $\begin{array}{ll}\text { ТЕТОВО } & \text { СКОПЈЕ } \\ \text { БИТОЉ } & \text { ПРИЛЕП }\end{array}$ од 19 до 27 новембра 1932 године

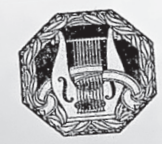

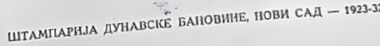

Figure 2. Concert program of the Music Society of Novi Sad for the tour around Serbia and South Serbia dedicated to Yugoslav choral music (November 19-27, 1932). Institute of Musicology SASA, Legacy of Svetolik Pašćan Kojanov, unsigned. 
Field research in Vardar Macedonia (and Kosovo) in the interwar period

That an institutional basis was a prerequisite for a systematical approach to collecting traditional folk music was clear to musicologists from Zagreb and Belgrade, who began to look for support from state authorities and already established cultural and scientific institutions as soon as 1920. Almost simultaneously, music scholars from both centers were looking for possible solutions to the problem of musical folklore research, so they turned to the officials of certain cultural institutions and state bodies. Musicologist and composer Božidar Širola (1889-1956) contacted the Ethnography Department of the Croatian National Museum in Zagreb, ${ }^{21}$ while his fellow musician and scholar Miloje Milojević (1884-1946) developed cordial relations with the Ethnographic Museum in Belgrade. ${ }^{22}$ The two institutions, together with the Ljubljana Royal Ethnographic Museum, became central in the process of collecting and exploring traditional music of different regions of Yugoslavia in the interwar period, although they faced many problems in achieving formal acknowledgement and proper financial support from the state for their folk music departments. ${ }^{23}$

Interestingly, the music material from Vardar Macedonia aroused interest and curiosity of both Belgrade and Zagreb in the 1920s, and as soon as the late 1920s Šrola went on fieldwork in the region of Lake Dojran, visiting, among others, the towns of Gevgelia and Kavadarci and writing down thirty melodies and various notes on folk dances, instruments and instrument playing. ${ }^{24}$ Since the Department of Folk Music he led as part of the Croatian National Museum started to use the phonograph in research in 1922, an idea was tabled two years later to organize field research in South Serbia in collaboration with music scholars from Belgrade. By that point, the Belgrade Ethnographic Museum had already established collaboration with Milojević, ${ }^{25}$ and Vladimir Đorđević, an able and esteemed folk music transcriber. However, despite the proposal of the museum's official Nikola Zega to the Serbian Royal Academy of Sciences to establish a Folk Music Department based on the claim that "collecting our folk melodies and songs is as significant as

\footnotetext{
${ }^{21}$ See Božidar Širola, Milovan Gavazzi, “Muzikološki rad Etnografskog muzeja u Zagrebu od osnutka do konca g. 1929 [Musicological activities of the Zagreb Ethnographic Museum from its foundation until the end of 1929]," Narodna starina 25 (1931): 3-80.

${ }^{22}$ See The Archives of Yugoslavia [Arhiv Jugoslavije (AJ)], Fond of the Ministry of Education of the Kingdom of Yugoslavia [Ministarstvo prosvete Kraljevine Jugoslavije] (66), 643-1067, Miloje Milojević, composer and teacher at the Third Belgrade Gymnasium to the Ministry of Education, March 24, 1920, Belgrade.

${ }^{23}$ Cf. Ivana Vesić, Vesna Peno, "Kosta P. Manojlović: A Portrait of the Artist and Intellectual in Turbulent Times," in Kosta P. Manojlović (1890-1949) and the Idea of Slavic and Balkan Cultural Unification, edited by Vesna Peno, Ivana Vesić, Aleksandar Vasić (Belgrade: Institute of Musicology SASA, 2017), 17-19; Širola, Gavazzi, "Muzikološki rad," 6-20.

24 Širola, Gavazzi, “Muzikološki rad,” 5.

${ }^{25}$ See Vesić, Peno, “Kosta P. Manojlović,” 18-19.
} 
the investigation and collecting of folk customs," it was not brought to fruition. ${ }^{26}$ This meant that the museum was open to experts who wanted to conduct field research, but was not able to support them financially. Instead, they were procured the material they needed and were probably provided expert assistance by the museum's employees. Still, the motives behind the organization of joint research by scholars from Zagreb and Belgrade for the purpose of phonographic recording of music in South Serbia are hard to discern from the available sources. Probably the Belgrade scholars were the initiators, and in the absence of their own equipment (phonograph) they decided to contact their colleagues in Zagreb, who were not only using phonographic recording in the field, but were also well informed on the technical part of the process. According to a preserved memo of the Zagreb museum's officials, joint field research was planned for the summer of 1924, and it was meant to include ethnologist Milovan Gavazzi (1895-1992) on their part. ${ }^{27}$ At first, the Ministry of Education gave approval for Vladimir Đorđević to represent the Belgrade museum, but subsequently replaced him with Kosta Manojlović (1890-1949), at the time a teacher at the Second Male Gymnasium in Belgrade. 28 Zagreb officials suggested the fieldwork be postponed to the autumn of 1924, since there were "insufficient wax plates, a malaria epidemic struck the region, there was ample seasonal work in rural areas," and they had also already made plans for a similar undertaking with Czech artist and passionate transcriber of folk tunes Ludvík Kuba (1863-1956). The joint project was never completed, but Manojlović, who was supposed to participate in it, managed to conduct a five-week research in the summer of 1924, visiting a number of places in Vardar Macedonia and Kosovo, and collecting 390 tunes. ${ }^{29}$ This fieldwork was most likely supported with the funds approved for the joint project. ${ }^{30}$

Manojlović's large-scale exploration of South Serbia was the first of its kind since the $19^{\text {th }}$ century, and as such attracted the interest of some of Belgrade's influential intellectual circles. One of the most prolific music critics and provocative writers at the time, Stanislav Vinaver, wrote an extensive and very inspired essay for the daily Vreme, where he presented some of Manojlovićs findings without hiding

\footnotetext{
26 See AJ, 66-643-1067, Belgrade Ethnographic Museum to the Arts Department of the Ministry of Education, No. 253, August 14, 1925, Belgrade.

27 See AJ, 66-643-1072, Ethnographic Department of the Croatian National Museum to the Arts Department, No. 70, June 27, 1924, Zagreb. Cf. Vesić, Peno, “Kosta P. Manojlović," 19.

28 Vesić, Peno, "Kosta P. Manojlović," 19.

${ }^{29}$ Based on Manojlović's testimony, it was not the first time he visited and explored this area. A year before (in 1923) he spent 15 days in Bitola, but the exact motives and results of this short fieldwork were left unexplained. See Kosta P. Manojlović, "Muzičke karakteristike našega Juga [Musical characteristics of our South]," Sveta Cecilija 5 (1925): 139.

${ }^{30}$ See Stanislav Vinaver, "Narod u punom jeku stvaranja. Otkrića i slutnje g. Koste Manojlovića [People in full creative swing. Findings and premonitions of Mr. Kosta Manojlović]," Vreme (October 2, 1924): 6.
} 
his enthusiasm. Vinaver depicted the trip through the prism of personal heroism of the researcher, his ascetic approach, strong devotion and discipline. ${ }^{31}$ As he stated:

Mr. Kosta Manojlović, who recently returned from South Serbia, is talking passionately about the harvest of motifs, folk motifs he found and collected there. He was given a meagre support of 4,000 dinars from the Arts Department [of the Ministry of Education], and he began his journey with a lot of love and austerity, living in very poor conditions, sleeping in stables, visiting the cottages of poor peasants, entering the shanties, where he wrote down the precious melodies of those people under candle light. [...] He would go to sleep after midnight, waking up before dawn, and rushing to places where he had heard there were good singers or old souls who once used to sing and were able to recall it. ${ }^{32}$

Vinaver's exuberant portrayal of Manojlovićs field research and his excited depiction of the specific qualities of "musicality" of South Serbians were meant not only to capture the attention of Vreme readers but they also laid the ground for similarly poetical representations of South Serbia by Gustav Krklec in his aforementioned reports on the Obilić tour and by Stanislav Krakov, who wrote a series of travelogues in the same paper in 1925. ${ }^{33}$

Manojlović used part of the collected material for the studies he published in Glasnik Profesorskog društva (The Bulletin of the Professors' Association), the journal Sveta Cecilija (Saint Cecilia) and Glasnik Etnografskog Muzeja (The Bulletin of the Ethnographic Museum) in 1925 and 1926. ${ }^{34}$ The findings from his fieldwork also served as a basis for his lengthy discussion intended for broader public titled Muzičko delo našeg sela (The Musical Oeuvre of Our Peasants) from 1929. Apart from presenting a portion of his transcriptions from the field, together with his insights and assumptions regarding the relations of traditional folk music of Vardar Macedonia with Serbian and Yugoslav musical folklore, Manojlović decided to catalogue the written tunes and create a collection within the Ethnographic Museum in Belgrade (see Figure 3). ${ }^{35}$ For that purpose, the museum's director Nikola Zega approved the printing of special forms needed for cataloguing.

\footnotetext{
${ }^{31}$ Ibid.

32 Ibid.

${ }^{33}$ Krakov's writings were published in September issues of Vreme. Cf. Vidosava Golubović, Letopis kulturnog života, 1919-1925: Vreme, Politika, Pravda [Chronicle of Cultural Life, 1919-1925: Vreme, Politika, Pravda] (Belgrade, Novi Sad: Institut za književnost i umetnost, Matica srpska, 1989), 352. ${ }^{34}$ Manojlović's writings on South Serbia from this period are listed in Srđan Atanasovski, "Kosta P. Manojlović and Narratives on 'Southern Serbia'," in Kosta P. Manojlović (1890-1949) and the Idea of Slavic and Balkan Cultural Unification, edited by Vesna Peno, Ivana Vesić, Aleksandar Vasić (Belgrade: Institute of Musicology SASA, 2017), 109-126.

35 See Manojlović, “Muzičke karakteristike našega Juga," 180; AJ, 66-643-1067, Ethnographic Museum in Belgrade to the Arts Department of the Ministry of Education, No. 253, August 14, 1925, Belgrade.
} 


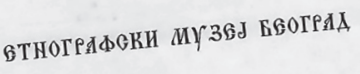

MYรHYКH DONKAOP

\section{5}

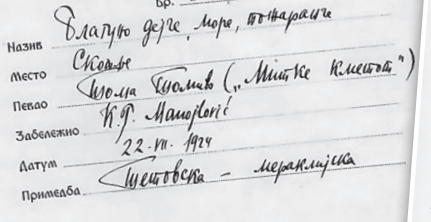

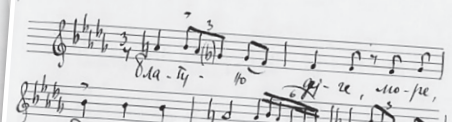

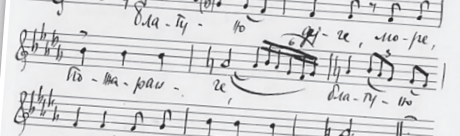

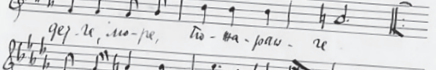

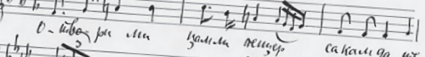

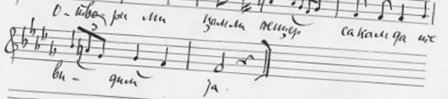

ia

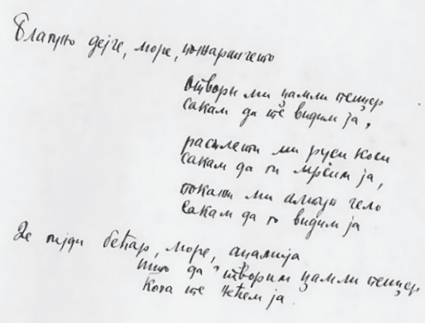

Figure 3. Filled-in form with data on the song "Blaguno dejče, more, požaranče" written down in Skopje on July 22, 1924. Institute of Musicology SASA, Kosta P. Manojlovićs digitized catalogues.

A year after Manojlović completed his field study, Vladimir Đorđević initiated an ambitious, four-month fieldwork aiming at exploring the various parts of South Serbia, particularly areas in Vardar Macedonia. This broad and detailed research was conducted without financial support from the state although Đorđević hoped for its assistance. Parts of his findings were published in Glasnik Skopskog naučnog društva in 1926, ${ }^{36}$ but the majority was presented in a large collection entitled Srpske narodne melodije (Južna Srbija) (Serbian Folk Tunes of South Serbia) published by the Skopje Scientific Society in 1928. It was the first collection of folk tunes that appeared in the "Serbian" part of the kingdom before the WWII, and the only one dedicated to the heritage of South Serbia. Unlike Manojlovićs undertaking, which was publicly admired and warmly received, Đorđevićs historically important publication received only a short, although very affirmative notice in the daily Pravda, primarily owing to its critic Petar Krstić, who valued Đorđevićs folk music research highly. ${ }^{37}$ With the exception of Krstić, who never missed an opportunity to point to

\footnotetext{
36 Đorđević explained how he used the material he collected and where the findings were published in the Preface to his second collection of folk tunes from prewar Serbia (Srpske narodne melodije: Predratna Srbija, Belgrade, 1931, XI).

37 See Petar Krstić, "Srpske narodne melodije (Južna Srbija). Skoplje, 1928 [Serbian folk tunes (South Serbia). Skopje, 1928],” Pravda (January 27, 1928): 7.
} 
his fellow composer and musicologist's precious work, ${ }^{38}$ other influential figures of musicology in Belgrade, particularly Milojević and Manojlović, were very reserved in this respect. ${ }^{39}$ Although further research would be needed to confirm this, the attitude of the musical authorities might have contributed to a sort of lukewarm reception of Đorđevićs collection at the time in both the professional and general public in Serbia and Yugoslavia.

Almost at the same time as Đorđević, this area was visited and explored by Czech painter and dedicated folklorist Ludvík Kuba, who was determined to complete his decades-long research on the traditional folk music of all Slavs, as well as his published series Slovanstvo ve svých zpèvech (Slavs in Their Songs), which he started in 1884. Kuba was well known among Yugoslav scholars, and his research and findings were followed with great interest and appreciation, particularly in Zagreb. ${ }^{40}$ The journal Sveta Cecilija published a number of his studies in the interwar period, and many reports regarding his work. Kuba's trip to South Serbia in the summer of 1925, the only Yugoslav region he had not had the chance to visit, attracted attention of several prominent Yugoslav papers. Announcing this undertaking, the daily Vreme praised Kuba's efforts and methodology in collecting Slavic and Yugoslav folk songs. ${ }^{41}$ Trying to underline his skillfulness and talent, the journalist referred to the words of Stjepan Radić, the leader of the Croatian Peasant Party, who claimed that none of Croatian politicians understood Dalmatia as fully as this Czech folk-music connoisseur. The Zagreb-based Nova Evropa (New Europe) magazine published an interview with Kuba after he finished his three-month South Serbia fieldwork focusing on the folk costumes and songs of

\footnotetext{
${ }^{38}$ See Ivana Vesić, "Konstruisanje srpske muzičke tradicije u periodu između dva svetska rata: uticaj ideoloških podela u srpskoj političkoj i intelektualnoj eliti [The construction of Serbian music tradition in the period between the two world wars: the influence of the division in the Serbian political and intellectual elite]," (PhD diss., Faculty of Philosophy of the University of Belgrade, 2016), 131.

${ }^{39}$ Still, as ethnomusicologist Dragoslav Dević claimed, Đorđević's collection was of great importance for Milojević during his field research in Vardar Macedonia. His personal copy was always close to him and he wrote down variants of tunes and lyrics in it with a red pen. See Dragoslav Dević, "Miloje Milojević, melograf i etnomuzikolog [Miloje Milojević collector of folks songs and ethnomusicologist]," in Narodne pesme i igre Kosova i Metohije, edited by Dragoslav Dević (Belgrade: Zavod za udžbenika i nastavna sredstva, Karić fondacija, 2004), 10. Unfortunately, at the time Dević conducted his exploration on Milojevićs ethnomusicological work, this copy was not at his disposal as it was displaced. The author of this chapter found this copy in the archival material of the Institute of Musicology SASA and, as soon as it is digitized, it will be available to all interested researchers.

${ }^{40}$ See, for instance, Božidar Širola, "Ludvik Kuba. O 60-godišnjici njegova života [Ludvík Kuba. On the occasion of his $60^{\text {th }}$ birthday]," Sveta Cecilija 4 (1923): 97-98.

41 "Srpske narodne melodije najinteresantnije su u Evropi. Razgovor sa g. Ludvikom Kubom, pred njegov put u Južnu Srbiju [Serbian folk tunes are the most interesting in Europe. An interview with Mr. Ludvík Kuba ahead of his journey to South Serbia]," Vreme (July 17, 1925): 4.
} 
that region. ${ }^{42}$ While showing respect and admiration for Kuba's lifelong project of collecting Slavic folk music, the journalist expressed particular curiosity in his impressions and judgements on South Serbian folk culture with respect to the longstanding political and diplomatic disputes between Serbs and Bulgarians. The Czech folklorist declared himself an ardent supporter of Pan-Slavism, and as such was very critical of the "fragmentation, either political or cultural," among Slavs at the time, especially South Slavs.

As a result of his field research, Kuba prepared a study on traditional Macedonian folk music, which was bought by the Folk Music Department of the Croatian National Museum, together with a portion of the transcribed material, and published in the Sveta Cecilija journal in 1927, owing much to the efforts of Milovan Gavazzi, the museum's curator, who was doing a doctorate in Prague in that time. 43

Before Miloje Milojević conducted his own fieldwork in the regions of Vardar Macedonia and Kosovo between 1927 and 1930, ${ }^{44}$ another joint project was proposed for collecting the music materials of these areas with a phonograph. This time the Zagreb Museum gave the initiative, asking other Yugoslav national and ethnographic museums for their contributions. ${ }^{45}$ The recording of South Serbian folk music was to be part of a very meticulously and ambitiously planned program that would be presented at the international exhibition Musik im Leben der Völker (Music in the Lives of the Peoples) organized in Frankfurt from early June until the end of August 1927 with the support of the Weimar Republic government. Museum officials wished to send Kosta Manojlović and Vladimir Đorđević to make phonographic recordings of selected melodies in the field, as well as to create "hard copies" of the wax plates. In order to display the richness of Yugoslav folk music from different parts of the country to the German and global public, authorities considered recordings, written accounts, published material and different objects including musical instruments, as well as a series lectures by domestic and foreign scholars. Among the lecturers to be invited were Ludvík Kuba, Curt Sachs and Robert Lach. Unfortunately, due to lack of financial support, the detailed and carefully conceived program of the musicologists and ethnologists from Zagreb was not realized. The absence of proper engagement of the Yugoslav political elite, specifically of the Ministry of Education

\footnotetext{
42 Jovan Kršić, "Ludvik Kuba u Makedoniji (jedan razgovor) [Ludvík Kuba in Macedonia (interview)]," Nova Evropa 1 (1926): 19-23.

${ }^{43}$ See Ludvík Kuba, "Pučka glazbena umjetnost u Makedoniji [Folk music art in Macedonia]," Sveta Cecilija 1, 2 (1927): 25-27, 76-81. Cf. Širola, Gavazzi, “Muzikološki rad,” 10.

44 See Dragoslav Dević, "Miloje Milojević, melograf i etnomuzikolog," 10.

45 See AJ, 66-634-1072, The memos of the Department of Folk Music of the Croatian National Museum/Croatian Ethnographic Museum to the Arts Department of the Ministry of Education on the Musik im Leben der Völker exhibition, No. 27/1, 1927, Zagreb; No. 27-6/1927, April 23, 1927, Zagreb; No. 27/8, 1927, Zagreb, May 24, 1927.
} 
and its Arts Department, triggered vigorous reactions of certain intellectual circles, which underlined with great disappointment the alleged detrimental effects of the country's unsystematic approach to cultural diplomacy. 46

Milojević conducted his field research in the areas of both Vardar Macedonia and Kosovo in the summer months for four consecutive years (1927-1930) (see Figure 4). As he was appointed associate professor at the Faculty of Philosophy in 1927, where he worked since 1925, it is possible that the first and some of his later trips were supported financially by the Belgrade University. In August 1928, Milojević turned to the Minister of Education, requesting material support in order to complement his previous research with more data from the field. In the letter, he also revealed his plan to prepare a publication on South Serbian traditional folk music, which he found necessary to support the "issue of our South regarding the national perspective" and at the same time "contradict the thesis of Bulgarians." 47 Although the Ministry of Education had no spare funds at its disposal for Milojevićs proposals, he continued his explorations in the following years. His first findings were presented in the several public lectures that took place in 1928 and 1929. As a member of a group of university professors under the patronage of the Ilija M. Kolarac Foundation, ${ }^{48}$ Milojević - accompanied by his wife, concert singer Ivanka Milojević-held a series of lectures on the traditional folk music from South Serbia, illustrated with song performances, in Skopje, Veles, Štip, Strumica, Prilep, Bitola, Ohrid and Kumanovo. ${ }^{49}$ His thoughts on South Serbian music presented on these occasions were published later that year in a standalone publication Južna Srbija u našoj kulturi. Narodna muzika Južne Srbije [South Serbia in our culture. The traditional folk music of South Serbia] (Belgrade, 1928). In June 1929, upon invitation by Jan Branberger, the dean of the Prague State Conservatory, Milojević spoke on the specific characteristics of Serbian traditional folk music to the Prague audience, focusing primarily on the South Serbian part. ${ }^{50}$ The lecture captured the interest of Czechoslovaks, but mostly because of the political incident instigated by Bulgarian students, who-embittered by Milojević's views on Vardar Macedonia-protested

\footnotetext{
${ }^{46}$ See Miloje Milojević, "Muzički pregled. Za spas naše muzičke kulture. Povodom muzičkog festivala u Frankfurtu na Majni [Music review. For the preservation of our music culture. On the occasion of the music festival in Frankfurt]," Srpski književni glasnik XXI/4 (1927): 296-301.

47 See AJ, 66-373-608, Miloje Milojević, composer and associate professor, to the Minister of Education, August 25, 1928, Belgrade (with the response of the General Department of the Ministry of Education, Pbr. 13495, August 25, 1928, Belgrade).

${ }^{48}$ See "G. Vladimir Ćorović o predavanjima Kolarčevog univerziteta po Južnoj Srbiji [Mr. Vladimir Ćorović on the lectures of the Kolarac University around South Serbia]," Vreme (February 15, 1928): 4.

${ }^{49}$ See "Kolarčev univerzitet u Južnoj Srbiji [The Kolarac University in South Serbia]," Vreme (February 15, 1928): 3.

50 See Srečko Koporc, “O srbski narodni pesmi [On Serbian folk songs]," Cerkveni glasbenik 9/10 (1929): 139-140.
} 


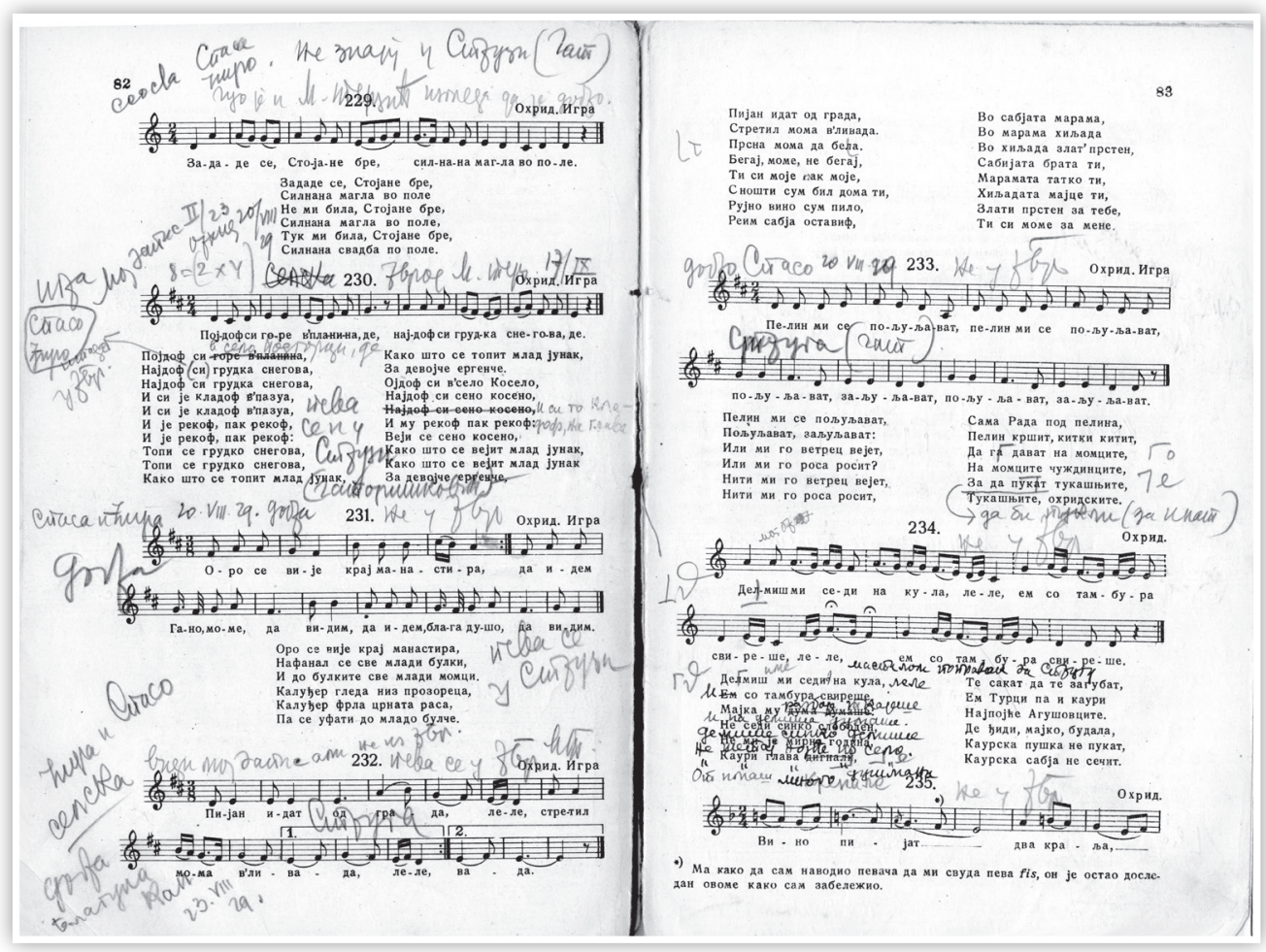

Figure 4. Miloje Milojevićs written down variants of tunes and lyrics of songs from Vardar Macedonia in his personal copy of Vladimir Đorđevićs 1928 collection. Institute of Musicology SASA.

furiously and left the event. ${ }^{51}$ Apart from the public lectures, Milojević also discussed materials and findings from his field research at the Third Congress of Slavic Geographers and Ethnographers in 1930, ${ }^{52}$ and almost a decade later in the prestigious literary and academic journal Srpski književni glasnik (Serbian Literary Gazette). ${ }^{53}$ Despite the announcement in the correspondence with the Ministry

\footnotetext{
51 Ibid., 140.

52 His work entitled "Nekoje odlike muzičkog folklora Južne Srbije" [Some characteristics of the musical folklore of South Serbia] was published in the proceedings of the Congress (Zbornik III Kongresa slovenskih geografa i etnografa u Kraljevini Jugoslaviji /1930/, Belgrade: Pripremni odbor II KSGGE, 1933, 235-246) and separately (Belgrade: Štamparija Davidović, 1932). Part of his finds were published in the second volume of his collection of studies and essays in 1933, in two chapters: "Jedna porečka pesma o Karađorđu [One song from Poreče region on Karađorđe]" and "Za tragom narodne melodije našeg juga [On the footsteps of folk melodies of our South]" (Belgrade: Izdavačka knjižarnica Gece Kona). They represent enlarged versions of Milojević's articles published in Politika in 1929 and 1930. 53 Miloje Milojević, "O tipu narodnih melodija Južne Srbije i o njihovoj izražajnoj snazi [On folk tunes of South Serbia and their expressive potential]," Srpski književni glasnik LVI/6 (1939): 441-446.
} 
of Education, Milojević never completed the book on the folk music practices of South Serbia, leaving a large portion of the collected material unpublished.

By the end of the 1920s, the "Serbian" part of the Kingdom was the only one that did not possess proper equipment for recording sound in field research, and these unfavorable circumstances were only changed owing to the efforts of the officials of the Belgrade Ethnographic Museum and its voluntary curator Kosta Manojlović. After a phonograph was procured in 1930, Manojlović, together with the museum's director and ethnologist Borivoje Drobnjaković and photographer Petar Petrović, made recordings in the area of the then Vardar Banovina (large part of former South Serbia) in 1931, and a year later (without Drobnjaković) in Debar, Struga, Ohrid, Bitola and Skopje. ${ }^{54}$ Due to technical problems with copying the wax plates to a more stable medium, phonograph recording in the field under the museum's supervision stopped. ${ }^{55}$ Manojlović continued his research in this area in the early 1940s under the patronage of the Belgrade Music Academy, where he was Chancellor (1937-1939) and professor. ${ }^{56}$

\section{Traditional folk music of Vardar Macedonia}

in relation to Serbian and Yugoslav music from the musicology perspective

With respect to the interest and general approach of Serbian musicologists to Macedonian folk music, several phenomena can be singled out. Firstly, throughout the interwar period and especially during the 1920s, the territory of Vardar Macedonia and partly Kosovo represented an area of particular significance for Serbian researchers concerning the collection and exploration of musical folklore. This is evidenced by the number and design of field studies that took place after the end of the Great War. No other region in the Kingdom of SCS/Yugoslavia has drawn such attention of Serbian music scholars and ethnographers of the time. Judging by the explanations they gave in the published results of their research, correspondence and reports in the press, there were several reasons why the area of Vardar Macedonia was an object of enormous interest to them. As already pointed out, one was the fact that this region had not been thoroughly investigated before since it belonged to the Ottoman Empire and could not be easily reached

\footnotetext{
${ }^{54}$ See Borivoje Drobnjaković's reports on the work of the Ethnographic Museum published in the museum's Bulletin (Glasnik Etnografskog muzeja) 5 (1930): 168-171, 6 (1931): 145-149, 7 (1932): 147-152; Cf. Danka Lajić Mihajlović, “Trag muzike urezan u vosku: kolekcija fonografskih snimaka iz Muzikološkog instituta SANU [The trace of music in wax: the collection of phonographic recordgings from the Institute of Musicology SASA]," Muzikologija 23 (2017): 239-258. Manojlovićs insights from these undertakings were published in the museum's journal in 1933 and 1935.

${ }^{55}$ Lajić Mihajlović, “Trag muzike urezan u vosku," 242-243.

56 See Dragoslav Dević, "Sakupljači narodnih melodija u Srbiji i njihove zbirke [The collectors of the folk tunes of Serbia and their publications]," Glasnik Etnografskog muzeja 22-23 (1960): 109.
} 
by researchers from neighboring countries. Another reason came from the belief in its authenticity. To be more specific, traditional folk music from this area was considered closer to the ancient Slavic musical practices because it was not influenced by other cultures as much as the music of other areas. The slow penetration of "civilizational" processes in this part of the former Ottoman Empire was thought to have resulted in the preservation of the authenticity of Vardar Macedonia's musical folklore and its centuries-old elements. The idea that the music from this region, as well as the region of Kosovo, represents the most typical product of South Slavs and Yugoslavs was suggested by composer Petar Konjović as early as 1920, and as it turned out in the coming years it resonated with the stances of most Serbian musicologists. Manojlović, for instance, emphasized the "purity" of the Slavic melodies particularly from the Poreče region (west Macedonia), ${ }^{57}$ while Milojević believed that the deeper layers expressed in South Serbian tunes bore the imprint of the authentically Slavic (South Slavic) character. ${ }^{58}$

Even more important for musicologists was the "originality" of the folk material from Vardar Macedonia and its extraordinary aesthetic qualities. This aspect held a prominent place in the discussions of Manojlović and Milojević. In his first writings after his field research, Manojlović was mesmerized by the polyrhythmic structure of the tunes of Vardar Macedonia (and Kosovo), and claimed that this element "is the most important characteristic of Yugoslav music," making the music from this region more interesting than the music of other parts of Yugoslavia. ${ }^{59}$ The constant changes in meter, together with metric accents, reminded him of modernist music, particularly of the early works of Igor Stravinsky. ${ }^{60}$ The impressive rhythmic qualities of music from South Serbia were also described with a passion in Vinaver's article, which he wrote as his artistic reshaping of Manojlović first-hand insights and testimonies from the field. As Vinaver noted referring to the material from the Poreče region: "The general characteristic of these ancient songs is the sudden change of rhythm. It cannot even be written down. Polyrhythm follows the song's psychology. [...] Particularly touching are the unusual rhythms, unusual in their frequent changes, in the songs about the Turkish villain Džemo, and the Serbian revenge." 61

Manojlović found melodic aspects of traditional folk music from South Serbia no less interesting than the rhythmic stressing and the modal basis of a majority of the collected material instead of the Western European major-minor

\footnotetext{
${ }^{57}$ Kosta Manojlović, Muzičko delo našeg sela [The Musical Oeuvre of Our Peasants] (Belgrade: Štamparija Tucović, 1929), 31.

58 Milojević, "O tipu narodnih melodija," 443.

${ }^{59}$ Manojlović, “Muzičke karakteristike,” 144, 139.

60 Ibid., 139.

61 Vinaver, "Narod u punom jeku stvaranja," 6.
} 
scale system. ${ }^{62}$ The only element that was not typically Slavic was the presence of the augmented second, which he interpreted as an influence of the Orient, 63 although, as he believed, not without potential and very interesting "for use in artistic music [...] since it became an integral part of our [Slavic] soul." The idea of assimilation of foreign, particularly oriental elements and their integration into the traditional folk music of this region was also underlined in the writings of Milojević and Đorđević. The latter was convinced that the "foreign components and features were not as they were in our music. They were given our character. They were redone and reshaped in our manner." In the same sense, Milojević believed that the South Serbian peasant:

created a synthesis of oriental and his own racial [ethnic] musical elements, with all the power of his sensibility and fantasy, and brightened up that synthesis with all the necessary attributes of his racial [ethnic] ego. This way he also succeeded to refract the oriental musical elements through the prism of his particularity, adapting them to his racial [ethnic] psyche, and depriving them of all the specific characteristics of oriental music mentality, in other words: he fertilized his soul and fantasy with the folk elements from the East, but did not imitate them literally, using instead their marks to make on his own the most beautiful folk melodies, ours and Balkan; ours because they are Balkan; and Balkan, that is ours. ${ }^{64}$

The assumption that foreign elements were well integrated into the musical material of South Serbia (and other regions), and that the amalgamation yielded interesting and aesthetically remarkable results ran contrary to the dominant views of music scholars expressed in the 1920s, when most of them thought it essential to preserve the purity of musical folklore, along with an elimination of unauthentic elements. ${ }^{65}$ The possible cause of the shift in their interpretations could be that the researchers became better acquainted with the material from the field by the late 1920s compared to the previous period, since it was unavailable before the mid-1920s.

Similarly to Manojlović, Milojević also believed that the music from South Serbia, especially its upper, surface layers, had an exceptional beauty to them in comparison with music from "other Serbian, Croatian and Slovenian provinces in Yugoslavia." ${ }^{66} \mathrm{He}$ explained it with the specific circumstances in which Slavic peasants lived under the Ottoman rule, namely with their "need to focus on themselves, [...] and, as they were full of emotional intensity and vivid fantasy to which

\footnotetext{
${ }^{62}$ Manojlović, "Muzičke karakteristike," 175.

${ }^{63}$ Ibid.

${ }^{64}$ Milojević, "O tipu narodnih melodija," 443-444.

${ }^{65}$ See Vesić, Konstruisanje srpske muzičke tradicije, 235.

${ }^{66}$ Milojević, "O tipu narodnih melodija," 442.
} 
they ought to give vent, they found it living in silence, withdrawn in the hardly accessible parts of the Balkans, in dialogue with their own sullen and terrified soul, full of yearning and dreams." ${ }^{7}$ From Milojevićs perspective, the continuous solitude intertwined with deep sorrow and "racial specificity" made South Serbians from the banks of the Vardar River, the slopes of Balkan mountains and the lakes of Dojran, Ohrid and Prespa the real poets.

Common to researchers of Vardar Macedonia's musical folklore was the assumption that it represented an integral part of the Serbian and Yugoslav music "idiom," finding evidence in certain characteristics it shared with the folklore of other regions of the country. The distinction manifested in the emphasis they put on its relatedness to the Serbian cultural space. Milojević and Đorđević followed to a great extent the terminology and discourse of Yugoslav (and Serbian) policies, not only by designating the folklore of this area as South Serbian, but also by adhering to the tripartite ethnic division of the kingdom into Serbian, Croatian and Slovenian regions. Milojević still clung to both the South Serbian label and the ethnic delineation in the 1930s when it was no longer in use, similarly to other musicologists, experts and academics. Kosta Manojlovićs approach to terminology was more complex. Although he did refer to South Serbia in several of his articles in the 1920s and 1930s, most of his writings on folklore at the time inclined toward the position of integral Yugoslavism with a strong influence of Pan-Slavism. Such a position disregarded the ethnic differences within Yugoslavia as insignificant for the exploration of folk music and emphasized the importance of geographical and ethnographical differentiation. Therefore, it is not surprising that Manojlović spoke primarily in terms of regions of the kingdom and their interconnections evident in different elements-similarity of rhythmic and melodic patterns, expressive tools, intervals, scales, etc. The interconnections were embedded in the sameness of the ethnic basis, above all Yugoslav and its very close South Slav version. According to Manojlović, the music of Vardar Macedonia showed distinctive features in comparison with the music north of the Šar Mountains-particularly Old Raška, Šumadija, Kosovo, Sandžak and Bosnia and Herzegovina-which contained certain common characteristics: "a serene musical thought, even with the combined rhythms, with deep sorrow and sensitivity, and something pastoral [...]." 68 Still, the regional specificities did not contradict the cohesion of the Yugoslav musical folklore. The fact that the same rhythmical patterns can be found in different regions of Yugoslavia was, for Manojlović, an indisputable indicator of the "ethnical unity of our peoples" and their cultural artefacts. ${ }^{69}$

\footnotetext{
${ }^{67}$ Ibid.

${ }^{68}$ Manojlović, Muzičko delo, 25.

${ }^{69}$ Ibid., 24.
} 
Vladimir Đorđević also pointed to the distinctions between the musical folklores of the South Serbian region and other regions, mentioning as examples Vojvodina, Dalmatia and Montenegro. Despite obvious differences, what these regions and other areas had in common was the rhythmical element and the "harmonic features" of melodies that showed persistence as well as resilience to foreign influence. As Đorđević stated, "the foreign elements did not alter the character of our traditional folk music, in the same way as the foreign words did not modify the character of our language." ${ }^{70}$ Milojević stressed the diversity of folk music of Yugoslav regions, which he believed to be the result of cultural, religious, geographical and social as well as climate-related factors. Observing "from the surface level of Yugoslav musical folklore, the extremely dissimilar characteristics of folk tunes of different areas of Yugoslavia are brought to the fore. Šumadija sings differently form Slovenia. Dalmatians had their own type of musical expression divergent from those of Croatian Zagorje or Međimurje, or the Vranje area." ${ }^{71}$ Concerning the music from South Serbia, Milojević was sure that it gave a completely unique accent to Yugoslav musical folklore. Although the "surface layer" manifested numerous contrasting features, Yugoslav musical folklore bore its own specific elements present in the "deeper layers" not perceivable to ordinary people. As Milojević pointed out, the "broader mass" had no sense of the significance of these deeply embedded bonds, despite the fact they are the "bearers of our common racial [ethnic] embryo."72

The Serbian music scholars who explored the folklore of Vardar Macedonia never questioned its belonging to the Serbian and Yugoslav cultural space, or felt the need to enter into discussion with Bulgarian scholars, who claimed exactly the opposite. When the collection Balgaro makedonski pesni (Bulgarian Macedonian Songs), collected and prepared by Josif Cheshmedziev, came out in Sofia in 1926, there was no reaction from Belgrade. Interestingly, the Zagreb-based journal of the Association of Musicians of the Kingdom of SCS, Muzičar (Musician) featured a short review of this publication in the special issue dedicated to Bulgarian music, ${ }^{73}$ created as a result of the initiative to bolster the relations among the musicians and music organizations of the two countries. In Božidar Širola's presentation of Czeshmedziev's work, any reference to Bulgarian nature of the collected material was carefully omitted. ${ }^{74}$ Even the title of the collection was not provided in its original form, and the review bore the title "Macedonian folk songs as arranged by Josif Cheshmedziev." Širola praised the undertaking of the young Bulgarian

\footnotetext{
70 Vladimir Đorđević, "Predgovor [Preface]," Srpske narodne melodije (Južna Srbija) (Skopje: Skopsko naučno društvo, 1928), XIII.

${ }^{71}$ Milojević, "O tipu narodnih melodija," 441.

72 Ibid., 442.

73 1928, No. 3.

74 Božidar Širola, "Makedonske pučke popijevke u odradbi Josifa Češmedžijeva [Macedonian folk songs as arranged by Josif Cheshmedziev]," Muzičar 3 (1928): 8-9.
} 
composer, using the opportunity to remind the readers of the explorations of Kosta Manojlović in "Old Serbia and Macedonia," as well as the insights of the "esteemed L. Kuba" concerning the characteristics of South Slavic folk songs. ${ }^{75}$

In the case of Kosta Manojlović, it is worth mentioning that he started intensive collaboration with renowned Bulgarian composer and musicologist Dobri Hristov in 1926, and later also with other Bulgarian musicians and musical organizations. ${ }^{76}$ It was probably as a result of his commitment to the project of South Slavic cultural integration, along with Yugoslav-Bulgarian rapprochement, that he consciously avoided the controversies of the Macedonian Question. Manojlović, as already stated, did not completely abandon the terminology of the Yugoslav political elite, but his interpretations were shaped in accordance with the discourses of Pan-Slavism and South Slavism, which contributed to minimizing the role of ethnical particularities, and put the emphasis on the supranational level (Yugoslav, South Slav). In Manojlovićs writings for the Institute of Balkan Studies in Belgrade after the mid-1930, the supranational perspective was replaced with an even broader stance stressing the importance of cultural transfers and amalgamation in the shaping of Yugoslav folk music, and its positioning in the "Balkan eastern music group." 77 Whether such classification resulted from a change in Manojlovićs views, or he simply conformed to the ideology of the editors and publishers of the book Knjiga o Balkanu (A Book About the Balkans) and their emphasis on the Balkans as a culturally specific and homogenous whole is hard to conclude from the available sources.

While Bulgarian scholars and writers on folk music of Vardar Macedonia were mostly ignored by their Serbian counterparts, this was not the case with other foreign authors who explored this area. For instance, Vladimir Đorđević wrote a short review of Ludvík Kuba's article on Macedonian music (published in Sveta Cecilija), underlining some of his most important insights and findings-that the foreign influences were fruitful for the music of this area, that it has a specific, individual character compared to other areas in Yugoslavia, that the augmented second is deeply integrated in it, and that it should be preserved. Đorđević found that Kuba, with his investigation and results, "contributed nicely to our unexplored musical folklore," for which he was "very grateful." 78 Unlike Đorđević, Manojlović did not express his views on Kuba's work in Vardar Macedonia, nor in other Yugoslav regions, but he did make a reference to his transcriptions of songs from Bosnia and Herzegovina in his book Muzičko delo našeg sela. ${ }^{79}$

\footnotetext{
75 Ibid.

76 See Vesić, Peno, "Kosta P. Manojlović," 20.

77 See Vesić, Konstruisanje srpske muzičke tradicije, 237.

78 Vladimir Đorđević, "Ludvik Kuba. Pučka glazbena umjetnost u Makedoniji (Sveta Cecilija, god. XXI, 1927, sv. 1-2, Zagreb)," Glasnik skopskog naučnog društva. Odeljenje društvenih nauka 3 (1928): 320.

${ }^{79}$ Manojlović, Muzičko delo, 58.
} 
By contrast, Milojević often commented on Kuba’s research emphasizing what he believed was his incompetence, dilettantism and a lack of proper knowledge and skills. Milojević spoke very critically of Kuba's work for the first time in the aforementioned public lecture in Prague. An interesting report on this event was written by Slovenian musician Srečko Koporc and published in the Cerkveni glasbenik (Church Musician) magazine, pointing to, among other things, a complete incongruity in the evaluation of Kuba's work between Bulgarian musicians and scholars and Milojević. ${ }^{80}$ In this respect, we should mention the generally very positive judgment of Kuba's endeavors by leading researchers of folk music in interwar Yugoslavia, such as Božidar Širola and the intellectual circles of Zagreb, as well as the group of musicians and scholars gathered around the magazine Sveta Cecilija. To Koporc's great disappointment, Milojevićs lecture on Serbian musical folklore focused on a narrow set of elements and criticism of Kuba's undertakings, leading him to the conclusion that the Serbian composer and musicologist "proved to be a better musician than scholar," alluding to the illustrations performed by him and his spouse Ivanka. ${ }^{81}$ In a similar vein, Milojević wrote a harsh critique of Kuba's review of Đorđevićs collection of South Serbian tunes for the Prague journal Tempo. ${ }^{82}$ Along with repeating his thoughts on Kuba's incompetence, Milojević underlined his allegedly "politically biased" position and like-mindedness with the propaganda of the Bulgarian political and intellectual elite:

Both in his collection of folk tunes from Macedonia-published by the Hudebni Matice-and on other occasions, Mr. Kuba expressed his opinion that Macedonia is close to Bulgaria with respect to its language and music. Professional music studies of Macedonia will show the character of this music, and the results of these studies will not coincide with the arbitrary, tendentious and dilettante conclusions of Mr. Kuba. But to prove that Mr. Kuba writes in the Czech journal with an obvious political motive, we will mention a few of his sentences: 'The book [...] contains 428 songs, 30 of which are from Old Serbia and the rest are from Macedonia, named Southern Serbia after the end of the WWI. This name was of purely political nature, because Macedonia, due to its language, was always considered a Bulgarian country by all European experts [...]. The book, good on the musical side, is not flawless as regards the language.' Also: 'the tunes should have been called Bulgarian, if they could not be termed Macedonian.' It is interesting to note that the author did

\footnotetext{
${ }^{80}$ Koporc, "O srbski narodni pesmi," 140.

81 Ibid.

${ }^{82}$ M[iloje]. M[ilojević]., “Beleške. Češki muzički časopis Tempo o muzici našeg juga [Notes. Czech music journal Tempo on the music of our South]," Srpski književni glasnik XXX/5 (1930): 391-392.
} 
not have the courage to label the texts as Serbian. The title was chosen in such a manner as if some of us were presenting Carpathian-Russian songs with the following title: Czech folk melodies: Eastern Czech Republic. This would have been impossible for us. ${ }^{83}$

Instead of providing counterarguments to Kuba’s claims, Milojević's conclusion once again aimed at discrediting him as a music ethnographer, asserting that the thesis he presented coincided with the "thesis promoted by the well-organized and subsidized Bulgarian propaganda." 84

Although a very short text and not so informative, Milojevićs review and the general approach of ignoring the Bulgarian aspect among music scholars illustrate the degree to which the Serbian and Yugoslav position on Vardar Macedonia was internalized, leaving no space for critical reevaluation or debate. Any attempt at this was assumed an act of either supporting Bulgarian propaganda activities or questioning the legitimate Serbian and Yugoslav claims. In the cases of Milojević, Đorđević and partly Manojlović, continuity of the prewar stance and interests with respect to folk music research was undeniable, alongside the already mentioned compliance with the interwar Yugoslav political discourse.

\section{Conclusion}

The assumption of unity of the Yugoslav cultural space, including the region of Vardar Macedonia, seems to have been broadly spread and accepted among the Serbian musicians and music scholars active in the interwar period, which is manifested in their discourse and actions. Not only did the elite music circles find Macedonian folk music an integral part of Yugoslav folklore, but they even gave it primacy over the folklore of other regions with respect to the creation of Yugoslav musical art. Such core position of the music of this area was particularly underlined by Manojlović and Milojević, mostly due to its aesthetic qualities. As Manojlović claimed for the folk music of South Serbia, "it holds a central place [in Yugoslavia], because in its heart it maybe already cradles the future Yugoslav genius." ${ }^{85}$ In a similar manner, Milojević thought of the music of this area "as the richest source of our musical nationalism, racially [ethnically] most typical, expressively most intense, inexhaustible source," which he personally "adores." ${ }^{66}$ Serbian scholars' almost unanimous understanding of the value of the musical folklore of Vardar Macedonia was not given an in-depth explanation in any of the published studies,

\footnotetext{
83 Ibid., 392.

${ }^{84}$ Ibidem.

${ }^{85}$ Manojlović, “Muzičke karakteristike," 180.

${ }^{86}$ Milojević, "O tipu narodnih melodija," 446.
} 
or the detailed comparisons with material from other Yugoslav regions. Therefore, it comes as no surprise that their conclusions left researchers familiar with the traditional folk music of different Yugoslav regions astounded. Ludvík Kuba, whose approach to Yugoslav folk music, including the music of Vardar Macedonia, was not under the influence of Yugoslav national and regional policies, observed them with much doubt and reserve. Commenting on the published findings of Kosta Manojlović concerning South Serbia, Kuba had the following comment:

Based on my own experience and familiarity with the material, as well as my comparative research of the music of different Slavic peoples in the Balkans, I cannot put Macedonia before other Yugoslav regions. [...] If I do not give Macedonian songs primacy over other Yugoslav tunes, I have a reason for that, based on my comparative findings. [...] How could the most beautiful and purest sprouts of Yugoslav song emerge in the regions that are not inhabited solely by Slavic peoples, such as Serbia and Bosnia and Herzegovina? In Old Serbia, Serbs are forced to keep up with Albanians, while in Macedonia, although the non-Slavs are a minority, there are many Albanian and Tzintzar enclaves, and the urban areas are populated with Greeks, Turks, Sephardic Jews, and Gypsies. Why would the genius of Yugoslav music of the future look for the substance in which to be reborn in this region? Why would his embryo grow right here?87

Although Kuba's critical assessment was based on empirical evidence including historical, ethnographic and ethnomusicological facts, his understanding of the music of Vardar Macedonia (and the all of South Serbia) was quite remote for that of the Serbian musical elite of the time. There are many possible reasons for that, but the influence of Western European musical modernism and its fascination with exoticism and "primitivism" certainly cannot be denied. Despite the fact that Manojlović, Đorđević and Milojević wanted to base their research on scientific methods, it seems that their composer's voice usually prevailed and had the last say. This phenomenon, together with the tendency of these researchers to strictly adhere to the terminology and cultural policies of the Yugoslav political elite, resulted in ambiguity and vagueness in many of their insights and findings. Furthermore, it explains the lack of interest to reexamine the positions of their predecessors on the one hand, and the need to complement their work in this domain following the logic and perspective they used on the other.

The research of Serbian music scholars in Vardar Macedonia not only reflected the dominant political concepts of the Serbian and Yugoslav elite regarding

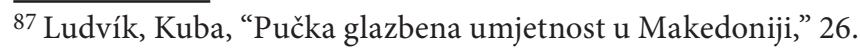


this area, but was also the result of their specific cultural policies. Considering the discrepancy between the research plans and efforts of scholars on the one hand and the state's support on the other, it seems that cultural policy makers of the Kingdom of SCS/Yugoslavia did not find collecting musical folklore a priority in the process of cultural integration of Yugoslavs, including "South Serbians," as well as in the international cultural exchange and promotion of the country. This is evident from their approach to individual research projects, as well as projects under the patronage of certain cultural institutions (museums), particularly during the 1920s. The lack of financial support from the state led to cancellation of research work, its postponing or overall reduction in its design, as well as different problems in the functioning of the folk music departments of the central ethnographic museums. Contrary to the claims of influential Bulgarian figures from the world of music at the time, the Yugoslav state did not intend nor ever gave "two million dinars" 88 for the purpose of researching the musical folklore of South Serbia. This situation did not profoundly change in the 1930s despite advances that were made in the representation of Yugoslav musical folklore abroad through the support of performances and tours of folk or other ensembles since the mid-1930s. Probably the new orientation in Yugoslav foreign policy in that period, specifically the rapprochement with Bulgaria and the signing of the Treaty of Eternal Friendship in $1937,{ }^{89}$ contributed to a great extent to such circumstances. Since folk music research in Vardar Macedonia could stir up the longstanding disputes between the two countries and provoke further controversies, it could be assumed that the status quo in this domain seemed as the most convenient solution. Still, a more in-depth examination of the internal and foreign cultural policies of the late 1930s and early 1940s should be conducted to clarify the role of certain factors in the process of collecting the musical folklore of Vardar Macedonia and other Yugoslav regions.

\footnotetext{
${ }^{88} \mathrm{~A}$ [ndrei]. P. Bersenev, "Voenoto-muzikalnoto delo (statiya chetvrta) [Military music legacy (part four)]," Muzikalen pregled 7 (1926): 3.

${ }^{89}$ More information on this topic can be found in Stefanka Georgieva's paper published in this volume.
} 


\section{Primary sources:}

Archives of Yugoslavia (AJ) (Belgrade): Ministry of Education of the Kingdom of Yugoslavia

Digital National Library of Serbia: http:// www.digitalna.nb.rs/
Digital Repository of the Svetozar Marković University Library: http://www.unilib.rs/ sadrzaji/digitalna-biblioteka/

Digital Library of Slovenia: http://www.dlib.si/ Old Croatian Journals (Portal of Digitized Journals): http://dnc.nsk.hr/Journals/

\section{References:}

Antić, Dejan D. "Političke prilike i srpski narod u Vardarskoj Makedoniji (1903-1912)." PhD diss., Faculty of Philosophy of the University of Niš, 2017. [Orig. in Serbian Cyrillic]

Atanasovski, Srđan. "Stevan Stojanović Mokranjac and Producing the Image of Serbian Folk-Song: Garlands from 'Old Serbia' as a Form of Musical Travelogue," Muzikološki zbornik 1 (2014): 75-90.

Atanasovski, Srđan. "Kosta P. Manojlović and Narratives on 'Southern Serbia.' In Kosta P. Manojlović (1890-1949) and the Idea of Slavic and Balkan Cultural Unification, edited by Vesna Peno, Ivana Vesić, Aleksandar Vasić, 109-126. Belgrade: Institute of Musicology SASA, 2017.

Atanasovski, Srđan. Mapiranje Stare Srbije. Stopama putopisaca, tragom narodne pesme. Belgrade: Biblioteka XX vek, 2017.

Avramovski, Živko (Ed.). Jugoslovensko-bugarski odnosi u XX veku. Vol. 1. Belgrade: Institut za savremenu istoriju, Narodna knjiga, 1980.

Avramovski, Živko (Ed.). Jugoslovenskobugarski odnosi u XX veku. Vol. 2. Belgrade: Institut za savremenu istoriju, Narodna knjiga, 1982.
Bersenev, A[ndrei]. P. "Voenoto-muzikalnoto delo (statiya chetvrta)." Muzikalen pregled 7 (1926): 3. [Orig. in Bulgarian Cyrillic]

Bogetić, Dragan, Kovačević, Slobodanka. Hronologija jugoslovensko-bugarskih odnosa 1878-2003. Belgrade: Jugoistok XXI, Centar za evro-balkansku saradnju, 2003.

Božić, Sofija. "Makedonija kao sporno pitanje između Srpske kraljevske akademije i Bugarske akademije nauka 1913.” In Balkanski ratovi 1912-1913: nova viđenja i tumačenja, edited by Srđan Rudić, Miljan Milkić, 381-392. Belgrade: Istorijski institut, Institut za strategijska istraživanja, 2013. [Orig. in Serbian Cyrillic]

"Danas se svečano otvara nova zgrada Narodnog pozorišta Kralja Aleksandra I." Vreme (October 27, 1927): 4. [Orig. in Serbian Cyrillic]

Dević, Dragoslav. "Sakupljači narodnih melodija u Srbiji i njihove zbirke." Glasnik Etnografskog muzeja 22-23 (1960): 99-122. [Orig. in Serbian Cyrillic]

Dević, Dragoslav, "Miloje Milojević, melograf i etnomuzikolog." In Miloje Milojević, Narodne pesme i igre Kosova $i$ Metohije, edited by Dragoslav Dević, 9-24. Belgrade: Zavod za udžbenika i nastavna sredstva, Karić fondacija, 2004. [Orig. in Serbian Cyrillic] 
Đorđević, Vladimir. "Ludvik Kuba. Pučka glazbena umjetnost u Makedoniji (Sveta Cecilija, god. XXI, 1927, sv. 1-2, Zagreb)." Glasnik skopskog naučnog društva. Odeljenje društvenih nauka 3 (1928): 320. [Orig. in Serbian Cyrillic]

Đorđević, Vladimir. "Predgovor.” Srpske narodne melodije (Južna Srbija). Skopje: Skopsko naučno društvo, 1928. XIII-XVIII. [Orig. in Serbian Cyrillic]

"G. Vladimir Ćorović o predavanjima Kolarčevog univerziteta po Južnoj Srbiji." Vreme (February 15, 1928): 4. [Orig. in Serbian Cyrillic]

Golubović, Vidosava. Letopis kulturnog života, 1919-1925: Vreme, Politika, Pravda. Belgrade, Novi Sad: Institut za književnost i umetnost, Matica srpska, 1989. [Orig. in Serbian Cyrillic]

Hadži-Vasiljević, Jovan. "Prilike pod kojima je postalo Društvo Sv. Save i njegov rad od postanka do sada." Bratstvo XVIII (1924): 1-14. [Orig. in Serbian Cyrillic]

"Izveštaj o radu Narodnog ženskog saveza Kraljevine SHS u 1924-25." Ženski pokret 8 (1925): 274-285. [Orig. in Serbian Cyrillic]

Jagodić, Miloš. "Planovi o politici Srbije prema Staroj Srbiji i Makedoniji (1878-1885)." Istorijski časopis LX (2011): 435-460. [Orig. in Serbian Cyrillic]

Jovanović, Vladan. "Demografske odlike Vardarske banovine i problemi samoidentifikacije." Etnoantropološki problemi 1 (2012): 563-584. [Orig. in Serbian Cyrillic]

Jovanović, Vladan. Jugoslovenska država i Južna Srbija 1918-1929. Makedonija, Sandžak i Kosovo i Metohija u Kraljevini SHS. Belgrade: Institut za noviju istoriju Srbije, 2002.
“Kolarčev univerzitet u Južnoj Srbiji.” Vreme (February 15, 1928): 3. [Orig. in Serbian Cyrillic]

Koporc, Srečko. "O srbski narodni pesmi." Cerkveni glasbenik 9/10 (1929): 139-140.

Krstić, Petar. "Srpske narodne melodije (Južna Srbija). Skoplje, 1928." Pravda (January 27, 1928): 7. [Orig. in Serbian Cyrillic]

Kršić, Jovan. "Ludvik Kuba u Makedoniji (jedan razgovor).” Nova Evropa 1 (1926): 19-23.

Kuba, Ludvík. "Pučka glazbena umjetnost u Makedoniji." Sveta Cecilija 1-2 (1927): 25-27, 76-81.

Lajić Mihajlović, Danka. “Trag muzike urezan u vosku: kolekcija fonografskih snimaka iz Muzikološkog instituta SANU." Muzikologija 23 (2017): 239-258. [Orig. in Serbian Cyrillic]

M[iloje]. M[ilojević]., "Beleške. Češki muzički časopis Tempo o muzici našeg juga." Srpski književni glasnik XXX/5 (1930): 391-392. [Orig. in Serbian Cyrillic]

Majdanac, Boro, Radojčić, Milena (Eds.). Akademsko pevačko društvo Obilić 18841941: dokumenti, sećanja, komentari. Belgrade: Istorijski arhiv Beograda, 2005. [Orig. in Serbian Cyrillic]

Manojlović, Kosta. "Muzičke karakteristike našega Juga.” Sveta Cecilija 5-6 (1925): 138-144, 174-180.

Manojlović, Kosta. Muzičko delo našeg sela. Belgrade: Štamparija Tucović, 1929. [Orig. in Serbian Cyrillic]

Milanović, Biljana. "Stevan Stojanović Mokranjac i aspekti etniciteta i nacionalizma." In Mokranjcu na dar, edited by Ivana Perković Radak, Tijana Popović Mlađenović, 33-53. Belgrade: Fakultet muzičke umetnosti, 2006. [Orig. in Serbian Cyrillic] 
Milojević, Miloje. "Beleške. Češki muzički časopis Tempo o muzici našeg juga." Srpski književni glasnik XXX/5 (1930): 391-392. [Orig. in Serbian Cyrillic]

Milojević, Miloje. "Muzički pregled. Za spas naše muzičke kulture. Povodom muzičkog festivala u Frankfurtu na Majni." Srpski književni glasnik XXI/4 (1927): 296-301. [Orig. in Serbian Cyrillic]

Milojević, Miloje. "O tipu narodnih melodija Južne Srbije i o njihovoj izražajnoj snazi." Srpski književni glasnik LVI/6 (1939): 441-446. [Orig. in Serbian Cyrillic]

Nedeljković, Slaviša. "Delovanje Odbora za škole i učitelje u srpskim oblastima u Makedoniji od 1868. do 1876." Vardarski zbornik 8 (2011): 283-305. [Orig. in Serbian Cyrillic]

"Pitanje o broju fakulteta (memoar komisije)." Prosvetni glasnik 2 (1928): 181-210. [Orig. in Serbian Cyrillic]

Roudometof, Victor. Collective Memory, National Identity, and Ethnic Conflict: Greece, Bulgaria, and the Macedonian Question. Praeger Publishers, 2002.

Roudometof, Victor (Ed.). The Macedonian Question: Culture, Historiography, Politics. East European Monographs, 2000.

Sotirović, Vladislav B. "Macedonia between Greek, Bulgarian, Albanian, and Serbian National Aspirations, 1870-1912." Serbian Studies: Journal of the North American Society for Serbian Studies 23/1 (2009): 17-40.

"Srpske narodne melodije najinteresantnije su u Evropi. Razgovor sa g. Ludvikom Kubom, pred njegov put u Južnu Srbiju." Vreme (July 17, 1925): 4. [Orig. in Serbian Cyrillic]
Širola, Božidar, Gavazzi, Milovan. "Muzikološki rad Etnografskog muzeja u Zagrebu od osnutka do konca g. 1929." Narodna starina 25 (1931): 3-80.

Širola, Božidar. "Ludvik Kuba. O 60-godišnjici njegova života." Sveta Cecilija 4 (1923): 97-98.

Širola, Božidar. "Makedonske pučke popijevke u odradbi Josifa Češmedžijeva." Muzičar 3 (1928): 8-9.

Trgovčević, Ljubinka. Naučnici Srbije i stvaranje jugoslovenske države 1914-1920. Belgrade: Narodna knjiga, Srpska književna zadruga, 1986. [Orig. in Serbian Cyrillic]

Vesić, Ivana. "Konstruisanje srpske muzičke tradicije u periodu između dva svetska rata: uticaj ideoloških podela u srpskoj političkoj i intelektualnoj eliti." PhD diss., Faculty of Philosophy of the University of Belgrade, 2016. [Orig. in Serbian Cyrillic]

Vesić, Ivana. Konstruisanje srpske muzičke tradicije u periodu izmedu dva svetska rata. Belgrade: Muzikološki institut SANU, 2018. [Orig. in Serbian Cyrillic]

Vesić, Ivana, Peno, Vesna. "Kosta P. Manojlović: A Portrait of the Artist and Intellectual in Turbulent Times." In Kosta P. Manojlović (1890-1949) and the Idea of Slavic and Balkan Cultural Unification, edited by Vesna Peno, Ivana Vesić, Aleksandar Vasić, 13-25. Belgrade: Institute of Musicology SASA, 2017.

Vinaver, Stanislav. "Narod u punom jeku stvaranja. Otkrića i slutnje g. Koste Manojlovića." Vreme (October 2, 1924): 6. [Orig. in Serbian Cyrillic] 